\title{
Introduction to the Bremerhaven Workshop on Biological Effects of Contaminants
}

\author{
A. R. D. Stebbing ${ }^{1}$, V. Dethlefsen ${ }^{2}$ \\ ' Plymouth Marine Laboratory, Prospect Place, The Hoe, Plymouth PL1 3DH, United Kingdom \\ ${ }^{2}$ Bundesforschungsanstalt für Fischerei, Institut für Fischereiökologie, AuBenstelle Cuxhaven, Deichstraße 12 , \\ W-2190 Cuxhaven, Germany
}

\begin{abstract}
A sea-going workshop on the biological effects techniques sponsored by the International Council for the Exploration of the Sea (ICES) and the Intergovernmental Oceanographic Commission (IOC) was held at the Alfred-Wegener Institute for Polar and Marine Research (AWI) in Bremerhaven, Germany, from 12 to 30 March 1990. The main objective was to test a wide range of biological effects techniques on contaminant gradients under the kind of conditions that they might be used in a monitoring programme. Two gradients in the North Sea were used; the first in the German Bight extending from the mouths of the Rivers Elbe and Weser out to the Dogger Bank, the second gradient related to an exploratory drilling site. The aim was to relate biological data to chemical analyses of contaminants in water, sediments and organisms taken during the workshop from the same stations on the same gradients. Over 100 scientists from countries bordering the North Sea, as well as from Sweden, Poland and North America, carried out joint investigations on the 2 transects, primarily to test and compare a wide range of established and new biological techniques to monitor the effects of pollution. The work included physiological, biochemical, embryological, molecular, cellular and gross pathological studies in the dab Limanda limanda, as well as various sediment and water quality bioassays and indices of benthic community change. Besides providing a database that could be used for selection of techniques for monitoring, the workshop identified a number of new problems related to pollution of the North Sea that should be addressed. These are listed in the concluding section of this volume. This MEPS Special Volume provides an account of all the results of the workshop, prefaced by several papers that give background information to help interpret the results of the workshop. The biological and chemical data are given in tabulated and graphical form in the Appendices to this volume.
\end{abstract}

\section{INTRODUCTION}

The sea-going Bremerhaven Workshop was first proposed in May 1987 at a meeting of the Working Group on the Biological Effects of Contaminants (WG BEC) of the International Council for the Exploration of the Sea (ICES). It was planned as a joint activity with the Group of Experts on the Effects of Pollution (GEEP) of the Intergovernmental Oceanographic Commission (IOC), and continued a series of practical workshops organised by GEEP. Both these international groups are dedicated to establishing biological techniques as a means of detecting and assessing marine pollution. The workshop series was initiated by the Oslo Workshop (Bayne et al. 1988) which was shore-based and deployed a number of techniques on a pollution gradient in the Oslofjord and Langesundfjord. The approach was then successfully applied in tropical waters during another shore-based workshop in Bermuda (Addison \& Clarke 1990). It was a natural progression to bring together the expertise of these 2 groups, in attempting to deploy biological effects techniques offshore. Much of the work was carried out on research vessels, or in the laboratory soon after coming ashore. Of necessity, samples for some of the biological techniques, and nearly all the analytical chemistry, were transferred to participating scientists' laboratories, as the most practical way to process them. Nevertheless, much of the work was done at sea and a number of the techniques were deployed offshore for the first time during the workshop.

The workshop was based, and much of the labora- 

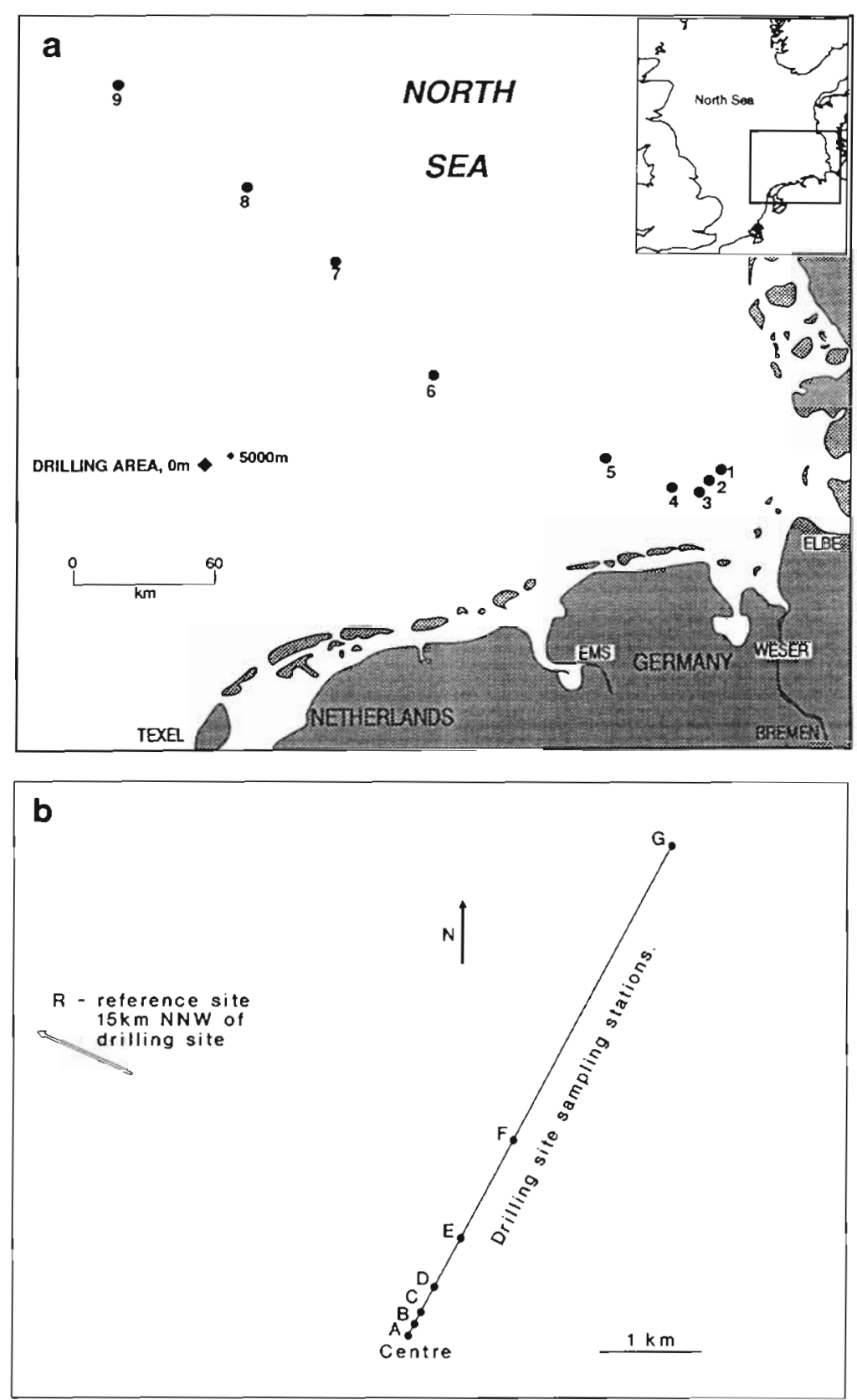

Fig. 1. (a) The German Bight showing the main transect (Stns 1 to 9) and that associated with the drilling site (Stns $A$ to $G$ ) with its reference site (R).

(b) The drilling site transect

tory work carried out, at the Alfred-Wegener Institute for Polar and Marine Research (AWI) in Bremerhaven, Germany, from 12 to 30 March 1990. Over 100 scientists from countries bordering the North Sea, as well as from Sweden, Poland and North America, deployed various biological and chemical techniques in the North Sea on board 7 research vessels and in the laboratories of the Alfred-Wegener Institute during the workshop.

Two North Sea areas were chosen for deploying techniques (Fig. 1): a transect of 9 stations running northwest from an area where the Rivers Elbe and Weser flow into the North Sea out to the Dogger Bank, and a second transect down-current from a disused drilling site off the Dutch coast. The second gradient was due to a single type of input (drilling muds) which had created a steeper gradient (Daan et al. 1992), less likely to be confounded by natural variables, or the complexity and number of inputs. The final format of the workshop was presented to the Statutory Meeting of ICES in The Hague in October 1989 (Stebbing et al. 1989).

The purpose of the Bremerhaven Workshop was to test the biological techniques by which contaminant effects might best be measured rather than to investigate any specific gradient. To this end transects were chosen based on known pollution gradients, and at points in the water column where contaminants are known to accumulate to concentrations more likely to cause toxic effects. Nevertheless, some interesting new observations concerning contaminant transport and sites of accumulation, and their possible effects, were made.

\section{RATIONALE FOR BIOLOGICAL EFFECTS TECHNIQUES}

Despite a clear rationale, and attempts dating back some years to identify and establish biological techniques in environmental monitoring programmes (MacIntyre \& Pearce 1980), such techniques have been slow to become adopted. If by 'quality' of the environment, we mean its capacity to sustain biological processes, the rationale for using biological techniques to assay sediment or water quality is clear. However, pollution monitoring has been dominated by the use of chemical analysis of contaminants, driven largely by the use of chemical criteria in pollution legislation. But such data only have relevance to environmental quality when expressed in terms of their biological implications, by relating concentrations to laboratory toxicity thresholds, for example. There is a strong case therefore to use biological monitoring techniques on a large scale and to focus chemical analytical effort where there are biologically demonstrable water or sediment quality problems.

Analytical chemistry also has its limitations in that 
concentrations do not necessarily indicate the bioavailable fraction, while the biota - by definition - can only respond to what is bioavailable. To rely upon chemical monitoring alone would presuppose that among the thousands of contaminants present in the effluent from the major European rivers, all those of biological significance are known and monitored. Biological techniques, on the other hand, provide an integrated response to the totality; to all the contaminants that contribute to the toxic load, whether they are known and monitored or not. It is primarily through the use of biological techniques that new or unsuspected contaminants of biological importance are first detected.

One weakness in using biological techniques is that while there is some certainty that a given concentration of a toxic substance will elicit a certain effect, observation of the effect alone helps little in identifying the cause(s). Generalised indices of stress are a natural choice for monitoring, but they respond to both natural and artificial stressors of all kinds. Specific indices are rare, although some identify the class of compound responsible for their induction (see Addison 1992, Moore 1992).

A key question is whether by the use of biological techniques it is intended to anticipate significant deleterious effects, or quantify retrospectively damage caused by pollution. Lethal effects, for example, are indicated by benthic community change, providing a retrospective view of damage done. Failure to recognise the anticipatory role of biochemical and cellular indices of toxic stress, providing forewarning of incipient deleterious effects, contributed at first to rejection of their environmental relevance and role in monitoring programmes. The case for using such indices has been slow to become accepted, but the links are now well enough established (Moore 1992) for EROD in dab Limanda limanda to have been adopted for use in the North Sea Task Force Master Monitoring Plan.

It is clear that neither biological nor chemical techniques alone can satisfy adequately the objectives of monitoring programmes. The unique advantages of biological techniques are to provide a measure of environmental quality that relates directly to our criteria for judging it, while having the capacity to integrate the effects of many contaminants over time and space. This must be the most cost-effective way to monitor European shelf waters on the scale and with the definition that is required. However causality cannot be established without appropriate spatially and temporally related chemical data for those contaminants responsible for the observed effects. The implication is that chemical analytical effort should be focused on those instances where there is a biologically demonstrable challenge to environmental quality. Within this workshop biological data are related in as closely coupled a manner as was practicable to a comprehensive chemical database of toxic contaminants in water, sediments and tissues.

\section{OBJECTIVES}

The primary objective of the Bremerhaven Workshop was to test and to compare a wide range of biological effects monitoring techniques, suitable for incorporating in monitoring programmes for the North Sea. It was therefore essential to do so in a realistic context on known contamination gradients from research vessels operating offshore.

The techniques tested during the workshop included the 4 selected by the North Sea Task Force (NSTF) for use in its Master Monitoring Plan. They are the oyster embryo bioassay for water and sediment, EROD and disease frequency in dab, and benthic macrofaunal community structure. The workshop provided an opportunity to compare these techniques during their first simultaneous deployment on the same contamination gradients, as well as many new techniques.

A clear theme that has emerged from this workshop, besides others in the series (Bayne et al. 1988, Addison \& Clarke 1990), is that biological effects techniques should never be deployed singly, but as a suite of techniques ranging over different levels of biological organisations. Different organisms may be exposed to contaminants with restricted distributions in specific phases and responses vary considerably in their specificity and sensitivity; their interpretation depends on whether they are adaptive responses expressing normal accommodation to toxic stress, or are deleterious effects from which recovery is unlikely. With the numerous indices indicating exposure to toxic stress in dab, it is now possible to link some effects in a hypothetical sequence of events leading to disease (Moore 1992), so that indices can be used and interpreted with a better understanding of the results of exposure.

The workshop also provided an opportunity to move forward understanding in several important areas of interest:

(1) Indices of health and disease in dab Limanda limanda. The workshop provided an opportunity to relate in a synoptic study a wide range of different indices of toxic stress and disease in the same fish on the same contaminant gradients. Techniques of biochemistry, molecular/cellular pathology and gross pathology were used on the dab Limanda limanda from a single gradient and often from the same fish. As EROD induction and gross pathology in dab had both been selected by the NSTF to monitor pollution in the North Sea, a comparative study relating effects and disease frequencies to a closely coupled chemical database for 
toxic contaminants on 2 gradients was timely. Where possible fish collected from the same stations at the same time were used for the biological measurements and tissue chemistry, providing the opportunity needed to integrate these different approaches to measuring the health of fish. In this way it was hoped to see to what extent the various indices gave results consistent with one another, besides relating these indices to levels of chemical contamination.

(2) Bioassays of water and sediment quality. Contaminants accumulate at interfaces; transiently at the sea surface (Hardy 1982) and more permanently on the sea bottom. Both interfaces are also regions of high biological activity, indicating that toxic effects are more likely to occur there. They present a good test for bioassay techniques, besides being appropriate sites to monitor. The workshop focused effort on deploying bioassay techniques to detect significant contamination and toxicity at the sea surface microlayer and at the superficial benthic sediments, as well as the water column

(3) Integrated measure of benthic environmental quality. While it is evident that sediment bioassays and benthic community structure linked to chemical analysis of the sediments are all likely to reflect benthic environmental quality, their most useful expression lies in some integrated interpretation of these data. An approach called the Triad, developed in North America (see Chapman 1992), was tested in European waters for the first time by its originators as part of the workshop.

\section{INTEGRATION WITH CHEMISTRY}

The rationale for relating biological measurements of environmental quality to chemical data for water, tissues and sediments in order to establish causality has already been stated, and is self-evident if the purpose of monitoring is to identify and ultimately control the chemical contaminants responsible for toxic effects. While historical data demonstrate stable contamination gradients associated with the Elbe/Weser plumes (Dethlefsen 1989) and the Dutch drilling platform (Daan et al. 1992), it was essential to have synoptic chemical data for compounds likely to be toxic to interpret the biological data from each gradient. The contaminant regime can change so rapidly that historical contaminant data may have little relevance. The effects of storms on the drilling site gradient immediately prior to the workshop (see Heip 1992, Rumohr \& Schomann 1992) demonstrated how rapidly a contamination gradient can be changed.

The ICES Marine Chemistry Working Group coordinated and provided appropriate organic and inorganic chemical analyses for tissue, water and sedi- ments, which involved 9 European laboratories. The report (Cofino et al. 1992) includes a contribution on metal chemistry from the former German Hydrographic Institute (Bundesamt für Seeschiffahrt und Hydrographie, BSH). In addition some chemical analyses were conducted during the workshop (Hardy \& Cleary 1992; sea surface microlayer samples), or independently, as for example the analyses of dab Limanda limanda tissues in relation to disease state (Protasowicki 1992).

\section{RATIONALE FOR CHOICE OF TRANSECTS}

Our intention in selecting contamination gradients for the Bremerhaven Workshop was not to identify gradients that required investigation in their own right, but to use gradients that would provide an adequate and realistic test of prospective iechniques for North Sea and other European monitoring programmes.

It is impossible on any field contamination gradient to eliminate the many natural variables that make the biological effects and responses to toxic contaminants difficult to interpret. However, such effects can be minimised by the choice of gradients. The criteria used in selecting the transects for the workshop were as follows:

(i) there existed an adequate historical data set for contaminants on each gradient to be sure that the transects represented a significant pollution gradient;

(ii) the transects were close enough to Bremerhaven to minimise passage time for the vessels;

(iii) organisms required for the workshop, particularly the dab Limanda limanda, occurred along the length of the transects;

(iv) natural variables unrelated to contamination, that might influence the responses of the biological techniques, were minimised (e.g. depth, sediment type).

\section{LOCATIONS OF TRANSECTS}

\section{German Bight transect}

The first transect consisted of 9 stations running northwest from a point off the mouths of the River Elbe and Weser to the most offshore station located over the northeastern arm of the Dogger Bank. It traverses a known contaminant gradient and is situated between $54^{\circ} \mathrm{N} 07^{\circ} 50^{\prime} \mathrm{E}$ and $56^{\circ} \mathrm{N} 03^{\circ} 24^{\prime} \mathrm{E}$ with a total length of approximately $200 \mathrm{~km}$ (Fig. 1a). Locations of the stations are given in Table 1 . It is entirely located on the German part of the continental shelf in an area routinely monitored and studied by the BSH and German 
Table 1. Locations of German Bight sampling stations

\begin{tabular}{|lllc|}
\hline $\begin{array}{l}\text { Stn } \\
\text { No. }\end{array}$ & Sediment & Co-ordinates & $\begin{array}{c}\text { Water depth } \\
(\mathrm{m})\end{array}$ \\
\hline 1 & Mud & $54^{\circ} 04^{\prime} \mathrm{N} 08^{\circ} 07^{\prime} 5^{\prime} \mathrm{E}$ & 19 \\
2 & Mud & $54^{\circ} 02^{\prime} \mathrm{N} 08^{\circ} 03^{\prime} \mathrm{E}$ & 27 \\
3 & Muddy sand & $54^{\circ} 00^{\prime} \mathrm{N} 08^{\circ} 00^{\prime} \mathrm{E}$ & 29 \\
4 & Muddy sand & $54^{\circ} 01^{\prime} \mathrm{N} 07^{\circ} 49^{\prime} \mathrm{E}$ & 36 \\
5 & Muddy sand & $54^{\circ} 06.5^{\prime} \mathrm{N} 07^{\circ} 24^{\prime} \mathrm{E}$ & 35 \\
6 & Muddy sand & $54^{\circ} 25^{\prime} \mathrm{N} 06^{\circ} 15^{\prime} \mathrm{E}$ & 40 \\
7 & Muddy sand & $54^{\circ} 50^{\prime} \mathrm{N} 05^{\circ} 35^{\prime} \mathrm{E}$ & 43 \\
8 & Muddy sand & $55^{\circ} 06^{\prime} \mathrm{N} 05^{\circ} 00^{\prime} \mathrm{E}$ & 42 \\
9 & Sand & $55^{\circ} 30^{\prime} \mathrm{N} 04^{\circ} 10^{\prime} \mathrm{E}$ & 30 \\
\hline
\end{tabular}

North Sea Programmes. Existing knowledge from such programmes was important in the planning stage, and is now important in interpreting the results of the workshop.

The main transect was selected with minimal variations in depth along its length, with significant differences in sediment contaminant concentrations and with a variety of contaminants (organochlorines, metals, polyaromatic hydrocarbons, petroleum hydrocarbons). Additional stations (Stns 1 to 3) were situated inshore of this transect to detect the effects of the river Elbe plume on the benthic community structure.

\section{Drilling site transect}

The second transect ran $5000 \mathrm{~m}$ down-current (WNW) of a disused drilling site off the Dutch coast (Fig. 1b). Station positions and distances from the site are given in Table 2 . The drilling site was selected because it minimises the effects of factors unrelated to the contaminants that the biological techniques were deployed to detect, by providing a point source and sharp decline in concentrations of drilling mud with distance. This area of the coast off the Netherlands was a site of exploratory drilling which was abandoned in 1987. Water and oil-based drilling muds are the major

Table 2. Locations of the Drilling Site sampling stations (see Fig. 1b). The site was located at $54^{\circ} 06^{\prime} 09^{\prime \prime} \mathrm{N} 04^{\circ} 45^{\prime} 25^{\prime \prime} \mathrm{E}$ and the transect was oriented in the direction of the residual current $\left(=66^{\circ}\right)$. R is the reference station $15 \mathrm{~km}$ NNW at

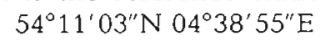

\begin{tabular}{|lr|}
\hline A & Centre \\
B & $125 \mathrm{~m}$ \\
C & $250 \mathrm{~m}$ \\
D & $500 \mathrm{~m}$ \\
E & $1000 \mathrm{~m}$ \\
F & $2000 \mathrm{~m}$ \\
G & $5000 \mathrm{~m}$ \\
R & $15000 \mathrm{~m}$ \\
\hline
\end{tabular}

contaminants which provided a clear gradient of biological impact on benthic community structure when studied earlier (see Daan et al. 1992).

\section{VESSELS AND SAMPLING PROGRAMME}

Details of the cruise schedules of the 7 research vessels are given in Table 3 .

\section{ORGANISATION OF THE WORKSHOP}

The group of projects in each disciplinary area were led by co-ordinators; these groups and their co-ordinators are given in Table 4 . This structure was maintained from an early planning stage, once proposals to participate had been accepted, through to the Concluding Meeting held in Copenhagen in September 1991, and is reflected in the present volume. The role of the co-ordinators has been crucial to such a complex workshop in ensuring provision of appropriate equipment and consumables beforehand, and providing intellectual focus and organising the work of their groups during the workshop itself at AWI in Bremerhaven.

The workshop not only originated from within the organisations of IOC and ICES, it also extended the series of workshops that IOC/GEEP initiated in Oslo. Through collaboration with ICES, and involving WG BEC, links were made with other ICES groups and their established techniques and procedures. In particular co-ordination of the chemical programme under Dr W. Cofino led to the participation of the Marine Chemistry Working Group, the co-ordination of the benthic community programme by Dr C. Heip involved the Benthos Ecology Working Group, while the co-ordination of the dab gross pathology and histopathology by Dr A. D. Vethaak led to the adoption of ICES guidelines and procedures of the Working Group on Pathology and Diseases of Marine Organisms. Overall statistical co-ordination was by Dr M. Carr helped by Dr S. Wilson, who incorporated the chemistry data in ICES database.

The effectiveness of collaboration of such groups in assessing the biological effects of pollution is evident from this volume, particularly in ensuring that there are simultaneous chemical measurements of the relevant toxic contaminants with which to relate observed effects. As important are the links into the Working Groups of ICES and the organisation of IOC, to ensure that what is learned is likely to be implemented, and the effectiveness of marine environmental monitoring and pollution control improved thereby.

The structure of the volume follows that set out in 
Table 3. Cruise schedule of the vessels that took part in the Bremerhaven Workshop. Dates and times of departure and return are given for all vessels; all vessels started and finished from Bremerhaven unless recorded otherwise

\begin{tabular}{|c|c|c|c|c|}
\hline Departure & & Return & & Area \\
\hline \multicolumn{5}{|l|}{ RV 'Viktor Hensen' } \\
\hline $1 \quad 12$ Mar $1990,13.30$ & & $15 \operatorname{Mar} 1990,02.00$ & & GB \\
\hline 215 Mar $1990,11.00$ & & 17 Mar $1990,04.00$ & & GB \\
\hline $319 \operatorname{Mar} 1990,12.00$ & & $20 \operatorname{Mar} 1990,07.00$ & & $\mathrm{~GB}$ \\
\hline 420 Mar $1990,11.55$ & & $22 \operatorname{Mar} 1990,07.00$ & & GB \\
\hline 526 Mar $1990,11.30$ & & 29 Mar $1990,00.30$ & & $\mathrm{~GB}$ \\
\hline \multicolumn{5}{|l|}{ RV 'Friedrich Heincke' } \\
\hline $112 \operatorname{Mar} 1990,14.00$ & Helgoland & $13 \operatorname{Mar} 1990,04.45$ & & GB \\
\hline 213 Mar $1990,13.00$ & & $14 \operatorname{Mar} 1990,07.00$ & & $\mathrm{~GB}$ \\
\hline 314 Mar $1990,13.00$ & & $15 \operatorname{Mar} 1990,07.00$ & & $\mathrm{~GB}$ \\
\hline 416 Mar $1990,06.00$ & & $22 \operatorname{Mar} 1990,06.45$ & & $\mathrm{~GB}$ \\
\hline 526 Mar $1990,14.40$ & & $28 \operatorname{Mar} 1990,09.10$ & & $\mathrm{~GB}$ \\
\hline 628 Mar $1990,16.00$ & & $29 \operatorname{Mar} 1990,15.00$ & & GB \\
\hline \multicolumn{5}{|l|}{ RV 'Solea' } \\
\hline 12 Mar $1990,19.00$ & & 17. Mar $1990,18.00$ & & $G B$ \\
\hline \multicolumn{5}{|l|}{ RV 'Walther Herwig' } \\
\hline $22 \operatorname{Mar} 1990,09.00$ & & $26 \operatorname{Mar} 1990,14.00$ & & $\mathrm{~GB}$ \\
\hline \multicolumn{5}{|l|}{ RV 'Valdivia' } \\
\hline 116 Mar $1990,07.00$ & Hamburg & 21 Mar $1990,07.00$ & Bremerhaven & $\mathrm{GB}$ \\
\hline 222 Miar $1990,07.00$ & & 28 Mar $1990,07.00$ & Hamburg & $\mathrm{GB}$ \\
\hline \multicolumn{5}{|l|}{ RV 'Aurelia' } \\
\hline $113 \operatorname{Mar} 1990,00.00$ & Scheveningen & $15 \operatorname{Mar} 1990,21.15$ & Den Helder & DS \\
\hline 226 Mar $1990,23.30$ & Den Helder & $29 \operatorname{Mar} 1990,13.13$ & Scheveningen & DS \\
\hline \multicolumn{5}{|l|}{ RV 'Holland' } \\
\hline 113 Mar $1990,00.00$ & Scheveningen & 15 Mar $1990,21.15$ & Den Helder & DS \\
\hline $226 \operatorname{Mar} 1990,23.30$ & Den Helder & $29 \operatorname{Mar} 1990,13.13$ & Scheveningen & $\mathrm{DS}+\mathrm{GB}$ \\
\hline
\end{tabular}

Table 4 and co-ordinators have been responsible for the refereeing and editing of the papers from members of their own group. The arrangements for refereeing Co-ordinators' papers and the Background papers

Table 4. Organisation of the Workshop, indicating the disciplinary areas into which the Bremerhaven Workshop was divided and the Co-ordinators responsible for leading each group of projects

\begin{tabular}{|ll} 
a. Fish dab Limanda limanda & \\
- Biochemistry & R. F. Addison \\
- Molecular and cellular pathology & M. N. Moore \\
- Gross- and histopathology & A. D. Vethat \\
b. Water quality bioassays & L. Karbe \\
c. Benthos & \\
- Community structure & C. Heip \\
- Sediment bioassays & P. M. Chapman \& \\
& R. C. Swartz \\
- Sediment Triad & P. M. Chapman \\
d. Chemistry & W. Cofino \\
e. Statistics & M. Carr \\
f. Vessels & V Dethlefsen
\end{tabular}

were made by the authors of this Introductory paper, who have been responsible for overall editorial policy.

\section{STRUCTURE OF THE SPECIAL VOLUME}

The structure of the volume reflects the organisation of the workshop (Table 4), and follows the programme for the Concluding Meeting of the workshop (September 1991, Copenhagen) at which all the results were presented for the first time. Experts were invited to prepare background papers in areas where additional knowledge was necessary to interpret the results of the workshop. This was especially important for the hydrography of the German Bight (Becker et al. 1992). The latest information on migration of the dab in the German Bight (Rijnsdorp et al. 1992) is necessary for the correct interpretation of fish disease as a measure of the effects of pollution (see Vethaak 1992). Essential background information on the drilling site gradient is provided by Daan et al. (1992), who describe the site and its contamination by drilling muds, and review 
their earlier studies which demonstrated a pollution gradient, relying on benthic ecology alone.

The background papers are concluded by the Workshop Chemistry Programme (Cofino et al. 1992), with a supplementary paper on dab tissue chemistry by Protasowicki (1992). Cofino et al. (1992) review the chemical programme and include some of the data in their paper. All of the data are included in Appendix 1 in tabulated form, and much of it in graphical form as well to assist interpretation of trends. As much of the chemical data as possible was distributed to all participants before writing their papers.

A major objective of the workshop was to make an inter-comparison of biological effects techniques, and it is clear from the papers which techniques were effective in discriminating the gradients. A closer comparison is possible by comparing graphs showing the biological responses in Appendix 2.

Each group of papers for each element of the workshop is prefaced by a Summary written by the Co-ordinator, outlining the main points emerging from his group. The reader should be aware that it is here that some of the key conclusions emerge: for example, explanation of the anomalous results from the drilling site gradient (see Heip 1992), and the integration of biochemical, histopathology and gross pathology indices in a hypothetical sequence of disease induction (see Moore 1992).

\section{A BRIEF CHRONOLOGY}

From its inception in May 1987 the scale and direction of planning has changed radically from a small workshop based on a single research vessel, to one that was shore-based at the Alfred-Wegener Institute, but with a fleet of 7 research vessels (Table 3) dedicated to the workshop and involving about 100 scientists. While many were from the IOC (GEEP) and ICES (WG BEC) communities, some of whom had been involved in the earlier workshops in the series, others responded to the open invitation published in the Marine Pollution Bulletin.

The format for the Bremerhaven Workshop was approved by the Fifth Session of the IOC Group of Experts on the Effects of Pollution in April 1989 (IOC 1989). Essentially the same proposal (Stebbing et al. 1989) was presented to the ICES Statutory Meeting in October 1989 and endorsed by the Marine Environmental Quality Committee (ICES 1989).

The workshop itself went ahead at the AlfredWegener Institute for Polar and Marine Research from 12 to 30 March 1990. A Preliminary Report was prepared within a month (ICES 1990) and subsequently an Interim Report summarised all of the biological and chemical data (Stebbing \& Dethlefsen 1991). Additional papers outlining the main conclusions from the workshop were given in 1990 to an IAWPRC/EWPCA Conference on 'North Sea Pollution' (Stebbing et al. 1990a), the Annual Meeting of SETAC, Washington (Stebbing et al. 1990b), and to an IOC Joint Meeting of the Group of Experts on the Effects of Pollutants (GEEP) and the Group of Experts on Methods, Standards and Intercalibration (GEMSI) in Moscow (Stebbing et al. 1990c). Following the workshop, the Planning Group and Co-ordinators met at the Institute for Environmental Studies in Amsterdam during June 1991 to consider outstanding questions, publication and to plan the Concluding Meeting for the workshop which was organised by ICES and held in Copenhagen in September 1991.

\section{LITERATURE CITED}

Addison, R. F. (1992). Biochemical measurements: summary. Mar. Ecol. Prog. Ser. 91: 61-63

Addison, R. F., Clarke, K. R. (1990). The IOC/GEEP Bermuda Workshop. J. exp. mar. Biol. Ecol. 138: 1-8

Bayne, B. L., Clarke, K. R., Grāy, J. S. (1988). Biological effects of pollutants. Results of a practical workshop. Mar. Ecol. Prog. Ser 46: 1-278

Becker, G., Dick, S., Dippner, J. W. (1992). Hydrography of the German Bight. Mar. Ecol. Prog. Ser. 91: 9-18

Chapman, P. M. (1992). Pollution status of North Sea sediments - an international integrative study. Mar. Ecol. Prog. Ser. 91: 313-322

Cofino, W. P., Smedes, F., de Jong, S. A., Abarnou, A., Boon, J. P., Oostingh, I., Davies, I. M., Klungsøyr, J., Wilhelmsen, S., Law, R. J., Whinnett, J. A., Schmidt, D., Wilson, S. (1992). The chemistry programme. Mar. Ecol. Prog. Ser. 91: $47-56$

Daan, R., van het Groenewoud, H., de Jong, S. A., Mulder, M. (1992). Physico-chemical and biological features of a drilling site in the North Sea, 1 year after discharges of oil-contaminated drill cuttings. Mar. Ecol. Prog. Ser. 91: 37-45

Dethlefsen, V. (1989). Proposed track for studies during the Bremerhaven Workshop on biological effects monitoring March 1990. In: ICES Report of the Working Group on Biological Effects of Contaminants. Aberdeen 9-12 May 1989. ICES, C.M. 1989/E:19

Hardy, J. T. (1982). The seasurface microlayer: biology, chemistry and anthropogenic enrichment. Prog. Oceanogr. 11: $307-328$

Hardy, J. T., Cleary, J. J. (1992). Surface microlayer contamination and toxicity in the German Bight. Mar. Ecol. Prog. Ser. 91: 203-210

Heip, C. (1992). Benthic studies: summary and conclusions. Mar. Ecol. Prog. Ser. 91; 265-268

ICES (1989). Procès-Verbal de la Réunion 1989. ICES, Copenhagen

ICES (1990). ICES/IOC Workshop on the biological effects of contaminants in the North Sea. In: Report of the Working Group on the Biological Effects of Contaminants. Nantes, France 24-26 April 1990. ICES, C.M. 1990/Poll: $4: \mathrm{E}$

IOC (1989). IOC-UNEP-IMO Group of experts on effects of pollutants. Fifth Session. IOC, Paris 
Macintyre, A. D., Pearce, J. B. (1980). Biological effects of manine pollution and the problems of monitoring. Rapp. P.-v. Réun. Cons. int. Explor. Mer 179: 1-346

Moore, M. N. (1992). Molecular and cellular pathology: summary. Mar. Ecol Prog. Ser. 91: 117-119

Protasowicki, M. (1992). Preliminary studies on selected elements in organs of dab Limanda limanda and their relation to fish disease state. Mar. Ecol. Prog. Ser. 91 $57-60$

Rijnsdorp, A. D., Vethaak, A. D., van Leeuwen, P. I. (1992). Population biology of dab Limanda limanda in the southeastern North Sea. Mar. Ecol. Prog. Ser. 91: 19-35

Rumohr, H., Schomann, H. (1992). REMOTS sediment profiles around an exploratory drilling rig in the Southern North Sea. Mar. Ecol. Prog. Ser. 91: 303-311

Stebbing, A. R. D., Dethlefsen, V., Heip, C., Thurberg, F (1989). ICES/IOC Workshop on the biological effects of contaminants, Bremerhaven, Federal Republic of Germany 12-30 March 1990. ICES, C. M. 1989/E:40
Stebbing, A. R. D., Dethlefsen, V., Thurberg, F. (1990a). Report on the ICES/IOC North Sea seagoing workshop. In: North Sea Pollution IAWPRC/EWPCA International Conference. Aquatech 1990, Amsterdam, The Netherlands 10-14 September 1990, p. 41-45

Stebbing, A. R. D., Dethlefsen, V., Thurberg, F. (1990b) Workshop to test biological techniques to monitor the North Sea. In: Global environmental issues: challenge for the 90s. 11th Annual SETAC Meeting, Washington (Abstracts), p. 35

Stebbing, A. R. D., Dethlefsen, V., Thurberg, F. (1990c). Draft Report on the ICES/IOC Workshop on the biological effects of contaminants in the North Sea. IOC-UNEP-IMO (EP-MSI) 7

Stebbing, A. R. D., Dethlefsen, V. (1991). Interim Report on the ICES/IOC Bremerhaven Workshop on biological effects techniques. ICES, C.M. 1991/E:6

Vethaak, A. D. (1992). Gross pathology and histopathology in fish: summary. Mar. Ecol. Prog. Ser. 91: 171-172 